\title{
A natureza ri da cultura ${ }^{1}$
}

\author{
Milton Hatoum \\ Escritor
}

Para Benedito Nunes

Ainda me lembro da voz de Emilie, a matriarca. Na minha infância, eu a escutava cantar e rezar, não em árabe, sua língua materna, mas em francês, sua língua adotada. Às vezes essa voz era abafada por outra, mais incisiva: a do meu avô, que evocava episódios de um Líbano cada vez mais distante. Mas a voz de Emilie - os sons mais que o sentido - era mais íntima. Nas noites da infância órfã, eu repetia mentalmente uma palavra ou um pedaço de frase, encantada com a reza e o canto, entregue a uma aprendizagem litúrgica, a um culto de que só nós duas participávamos.

Não era apenas a voz de Emilie que contrariava o patriarca da casa. Ela, Emilie, tinha uns amigos que meu avô considerava esnobes e altivos. Quando esses amigos se reuniam em casa para jogar gamão ou conversar e fumar narguilé sob a parreira do pátio, meu avô ficava calado, e seu olhar dizia que as visitas eram inconvenientes. Mas o velho não se importava quando Emilie citava com frequência dois amigos esquisitos e esquivos. Um deles era Armand Verne: "um homem muito imaginoso, com trejeitos de dândi e que já morou em Lisboa, Luanda e Macau antes de chegar a Manaus".

Armand Verne falava vários idiomas e era um estudioso de línguas indígenas. Em Manaus, empenhavase em realizar um curioso trabalho filantrópico: insuflar (discretamente) os índios contra os padres e patrões e promover a cultura indígena. Para tanto, fundou a Sociedade Montesquieu do Amazonas, cujo lema era "educar para libertar".

Felix Delatour, o outro amigo de Emilie, era um bretão circunspeto, quase albino, que sofria de uma enfermidade rara: o gigantismo. Lecionava francês e, ao contrário de Verne, nunca fundou uma sociedade filantrópica ou algo semelhante. Os amigos esnobes de Emilie não me interessavam, mas Felix Delatour e Armand Verne aguçaram minha curiosidade.

\footnotetext{
Do livro de contos $A$ cidade ilhada, Companhia das Letras, São Paulo, 2009. Publicado com autorização do escritor.
}

Quando ela soube que queria estudar francês, disse que eu devia visitar monsieur Delatour já no dia seguinte: era o francês mais excêntrico do Amazonas.

No primeiro encontro, numa manhã de julho de 1959, ele foi lacônico. A jovem magra e tímida vê a estátua de uma Diana no meio de um jardim, atravessa um pequeno pátio e bate na porta de madeira. Na porta entreaberta, só pude ver a metade de um rosto de cera; parecia que o homem curvava a cabeça e o corpo. Com voz hesitante, murmurei: Minha avó Emilie me disse que o senhor ensina francês.

Ele me observou por um momento, então ouvi uma voz áspera: Faz tempo que não leciono, mas podes entrar.

Quando Delatour abriu a porta, logo notei sua estatura de gigante. Tudo ao meu redor encolheu. Na sala escura, a mobília era um amontoado de sombras. Não sei por quê, ele sempre evitou frequentar esse lugar da casa; na verdade, só conheci o andar superior: um quarto amplo e avarandado, de onde se via um horizonte de águas escuras. No centro do quarto, uma mesa de madeira e duas cadeiras de vime; quatro livros abertos e quatro lápis vermelhos estavam alinhados sobre a mesa. Um mapamúndi, fixado na parede branca, hoje ressurge na minha memória como uma câmera de luz intensa.

Nos meses seguintes, Delatour pouco falou sobre a língua francesa; quando eu lhe pedia uma explicação gramatical, ele desviava a conversa, enfadado. Soube que deixara a Bretanha havia muitos anos; seu desejo era partir em busca do desconhecido. Para ele, viajar era uma forma de viver em tempos distintos. Um dia lhe perguntei se conhecia o dialeto bretão ou uma das tantas línguas indígenas do Amazonas. Vi seu rosto branco ruborizar: um rosto sem rugas, imberbe, os olhos azulados pareciam expressar dúvida ou indagação; de repente se levantou, foi até a varanda e, de costas para o rio, disse:

Emilie me confundiu com Armand Verne. Ele, sim, é um linguista aplicado e tutor dos nativos. Verne pensa que pode promover a cultura indígena elaborando cartilhas bilíngues. É um equívoco: não se pode dominar 
totalmente um idioma estrangeiro, porque ninguém pode ser totalmente outro. Um deslize no sotaque ou na entonação já marca uma distância entre os idiomas, e essa distância é fundamental para manter o mistério da língua nativa.

$\mathrm{Na}$ voz de Delatour, um forte sotaque reiterava sua afirmação. Venci a timidez e fiz outras perguntas: por que tinha vindo ao Amazonas? Por que morar em Manaus, esta cidade ilhada, talvez perdida?

Ele olhou para o mapa-múndi, apontou uma região da França:

Ali passei minha infância.

Onde?

No Finistère, num vilarejo ilhado e talvez perdido. Certa vez, um viajante bretão que andou pela Amazônia me deu de presente o mapa dessa região. E os mapas, como tu sabes, fascinam as crianças, são desenhos misteriosos que as convidam a fazer viagens imaginárias. Os périplos da minha infância, irreais como os sonhos, começaram nos limites do quarto fechado, à espera do sono, não longe do mar e das falésias abruptas da Bretanha.

Por algum tempo não tocamos no assunto. Às vezes, nada dizíamos; no quarto branco, iluminado pelo sol, escutávamos o barulho de um barco, monótono, como uma paisagem repetida. Enquanto eu pensava em alguma pergunta ou dúvida, Delatour lia um livro e fazia anotações com um lápis vermelho. Os gritos, a zoada do Mercado Municipal, a quentura do clima, nada o incomodava. Era um leitor que parecia dialogar com o texto, e isso, para mim, era uma novidade, uma descoberta.

Uma manhã, alguém bateu à porta. Delatour desceu para ver quem era, e depois escutei a voz de uma mulher. Passei a folhear um dos livros abertos. A voz feminina me deixou curiosa e, quando Delatour voltou ao quarto, disse que a índia Leonila não era uma visita qualquer. Ela pedia para entrar, observava os livros da biblioteca, cochilava na rede do quintal e ia embora sem aviso. Andava descalça, vestia sempre a mesma roupa, podia ser confundida com um mendigo. Mas é uma mulher que conhece a história de sua tribo, continuou Delatour, olhando para mim como nunca olhara antes. Um dia, sem que eu lhe pedisse, Leonila começou a falar sobre a história, a violência, os mitos. Armand Verne também aprendeu muito com ela, mas insiste em querer falar por ela.

Alguma coisa havia entre Felix Delatour e Armand Verne, mas eu não quis abelhudar. Emilie nada me contou a esse respeito, apenas disse: Verne viaja no espaço, e Delatour, no tempo.

$\mathrm{Na}$ manhã da visita de Leonila, ele notou que eu folheava um livro, e então passou a ler em voz alta poemas de Rimbaud. Depois me pedia que os recitasse sem imitar seu sotaque.

Não consigo entender muita coisa.
Por enquanto, isso é o de menos, sorriu Delatour. O que importa, agora, é encontrar outra voz de Rimbaud ou apenas captar o ritmo e a melodia de cada verso.

Andou até a varanda, o rosto voltado para o horizonte.

À primeira vista, a floresta parece uma linha escura além do rio Negro, disse ele. Não se consegue distinguir muita coisa. Mas no interior de tanta escuridão há um mundo em movimento, milhões de seres vivos, expostos à luz e à sombra. A natureza é o que há de mais misterioso.

Delatour citou como exemplo o mapa da Amazônia que o encantara na infância. Para ele, a floresta era um mundo quase inverossímil, e por isso mesmo fascinante. Chegou a construir uma floresta em miniatura, estriada por uma teia de rios cujos nomes de origem indígena ele pronunciava como um bárbaro.

A imaginação se nutre de coisas distantes no espaço e no tempo, mas a linguagem encontra-se no tempo, afirmou, como se falasse para si mesmo.

Ele fez esse comentário poucos meses antes de eu partir de Manaus. Quando soube que eu queria morar em São Paulo, disse coisas que nunca esqueci: A viagem, além de tornar o ser humano mais silencioso, depura o olhar.

Depois acrescentou que não se referia a uma vida de aventuras, como a do viajante seduzido por um mistério. Disse: O que mais me interessa é a aventura do conhecimento.

$\mathrm{Na}$ véspera do meu embarque para Santos, ele me deu uma plaqueta em cuja capa se lê Voyage sans fin ${ }^{2}$.

Comecei a escrever esse texto no Finistère e terminei aqui em Manaus, disse Delatour. Quase vinte anos para escrever isso, uma página por ano, poucas palavras por dia.

Não escondia uma expressão de desânimo, talvez fadiga. Ele se curvou para me dar um abraço, e desapareceu entre os livros.

$\mathrm{Na}$ madrugada do dia seguinte, Emilie e meu avô me acompanharam até o Manaus Harbour, onde eu ia embarcar num navio da Booth Line. Perguntei a Emilie se Armand Verne realmente acreditava no trabalho da Sociedade Montesquieu do Amazonas. Emilie não respondeu, mas meu avô disse que Verne era um viajante incansável, um andarilho que colecionava lendas e mitos da Amazônia. Um homem que se apropriava da cultura dos nativos, com a esperança de salvá-los.

Escutamos o apito grave e breve da sirene do Cyril, e observamos a bordo o vaivém dos estivadores e marinheiros. As gruas do cais flutuante estavam iluminadas. Luar não havia, nem vento. Talvez um leve sopro, úmido, vindo do fim da noite.

\footnotetext{
2 Manaus: Editora Palais Royal, sem data.
} 
A bordo do Cyril, e já próximo de Recife, comecei a ler a plaqueta de Delatour. Naquela época me pareceu um texto enigmático, mas a leitora de 1959 não é a leitora desta noite. Hoje, depois de relê-lo tantas vezes, soa como um manifesto poético de um narrador-personagem que abandona um país europeu para morar numa região equatorial. Com o passar do tempo, o personagem percebe, apreensivo, que o estigma de ser estrangeiro já é menos visível: algo no seu comportamento ou na sua voz se turvou, perdeu um pouco do relevo original. Nesse momento, as origens do estrangeiro sofrem um abalo. A viagem permite a convivência com o outro, e aí reside a confusão, fusão de origens, perda de alguma coisa, surgimento de outro olhar. Viajar, pergunta o personagem de Delatour, não é entregar-se ao ritual (ainda que simbólico) do canibalismo? Todo viajante, mesmo o mais esclarecido, corre o risco de julgar o outro. Consciente ou não, intencional ou superficial, tal julgamento quase sempre deforma o rosto alheio, e esse rosto deformado espelha os horrores do estrangeiro. Nesse convívio com o estranho, o narrador privilegia o olhar: o desejo de possuir e ser possuído, a entrega e a rejeição, o temor de se perder no outro.

De onde parte o personagem-viajante de Delatour? De Cancale, na Bretanha, "um porto tão estranho que ninguém ou quase ninguém é capaz de deixá-lo". Em Cancale começa a travessia oceânica, uma travessia tempestuosa que termina num porto também estranho do hemisfério sul: um lugar sem nome, ilhado, habitado por pessoas que parecem resignadas ao confinamento e à clausura.
Na passagem mais enigmática do texto, o narrador, ao evocar esse porto, acaba inventando uma linguagem. $\mathrm{O}$ ritmo da frase altera-se bruscamente e a voz do personagem se torna um disparate gramatical e uma confusão de neologismos e perplexidades. Lembra a voz de um louco vociferando em várias línguas ${ }^{3}$. São apenas doze linhas que destoam do relato, como uma breve festa de sons, ou uma explosão numa noite serena. Por causa desse trecho, nunca traduzi Viagem sem fim.

Mais de dez anos se passaram entre o encontro com Delatour e o meu regresso a Manaus. Eu o procurei por toda a cidade, em vão. Emilie, com uma voz fraca que parecia um sopro, disse que em janeiro de 1971 ele subiu o rio Negro até a fronteira com a Colômbia. Nunca mais soube dele.

No consulado da França em Manaus não consegui nenhuma pista sobre o destino de Delatour. De manhã cedo fui visitar o sobrado em que ele morava, numa das ruas que desembocam no rio Negro. Uma casa em ruínas: raízes de um apuizeiro estrangulam a estátua da Diana e ameaçam derrubar uma parede que foi branca. Crianças imundas e miseráveis cheiram cola; uma delas, com um pedaço de carvão, garatuja o muro que cerca o jardim; outras, deitadas no pátio, acariciam um cão magro, de pelagem escura. Um cheiro de podridão e excremento emana da sala, o espaço da biblioteca. Na parede externa, li uma frase curiosa escrita a cal: "A natureza ri da cultura".

Antes de me afastar do sobrado, a criança que rabiscava o muro se volta para mim. Calada, imóvel, com o pedaço de carvão na mão direita, a criança me olha com estranheza.

\footnotetext{
3 Nessa passagem do texto de Delatour, a linguista Odette Lescure encontrou referências dialetais usadas por índios e caboclos do Amazonas. Na verdade, são "traduções" de palavras e expressões das línguas nheengatu, tukano e baniwa faladas na região do Alto Rio Negro.
} 